\title{
PENGGUNAAN EKSTRAK DAUN JAMBU BIJI (Psidium guajava L.) SEBAGAI OVISIDA KEONG MAS (Pomacea canaliculata L.)
}

\author{
RINA BUDI SATIYARTI ${ }^{*}$, YULI YANA ${ }^{1}$, DAN FATIMATUZZAHRA ${ }^{1}$ \\ ${ }^{1}$ Program Studi Pendidikan Biologi, Fakultas Tarbiyah dan Keguruan, UIN Raden Intan Lampung, \\ Jl. Endro Suratmin, Sukarame, Kota Bandar Lampung \\ *alamat email korespondensi: rinabudisatiyarti@radenintan.ac.id
}

\begin{tabular}{|c|c|}
\hline Informasi Artikel & Abstrak/Abstract \\
\hline $\begin{array}{l}\text { Riwayat Naskah : } \\
\text { Diterima pada } 27 \\
\text { Mei } 2019 \\
\text { Diterima setelah } \\
\text { direvisi pada } 4 \text { Juli } \\
2019 \\
\text { Diterbitkan pada } 5 \\
\text { Juli } 2019\end{array}$ & $\begin{array}{l}\text { Keong mas adalah hama bagi tanaman padi. Hama keong mas akan memakan batang padi } \\
\text { dalam waktu yang relatif singkat, sehingga kehadiran keong mas pada tanaman padi dapat } \\
\text { menggagalkan panen. Penggunaan pestisida sintetik dalam penanggulanan telur dan keong } \\
\text { mas dewasa tubuh telah diketahui dapat mencemari lingkungan sekitar. Terlebih lagi, } \\
\text { pestisida sintetik dapat menyebabkan resistensi vektor. Penggunaan pestisida nabati hanya } \\
\text { dapat mematikan keong mas dewasa tubuh, tetapi tidak untuk telurnya. Oleh karena itu, } \\
\text { dibutuhkan pestisida nabati yang dapat mematikan keong mas sejak tahap menjadi telur. Daun } \\
\text { jambu biji (Psidium guajava } L \text {.) mempunyai senyawa yang mengandung saponin, flavonoid, } \\
\text { tanin, terpenoid dan alkaloid yang diperkirakan dapat menghambat daya tetas telur (ovisida). } \\
\text { Penelitian ini termasuk ke dalam penelitian eksperimental. Desain penelitian ini menggunakan }\end{array}$ \\
\hline $\begin{array}{l}\text { Kata Kunci: Daun } \\
\text { Jambu Biji (Psidium } \\
\text { guajava L.), Keong } \\
\text { Mas (Pomacea } \\
\text { canaliculata L.), } \\
\text { Pestisida, Ovisida, } \\
\text { ekstrak daun jambu } \\
\text { biji. }\end{array}$ & $\begin{array}{l}\text { Rancangan Acak Lengkap (RAL). Konsentrasi daun jambu yag digunakan adalah } 1 \%, 1,5 \% \text {, } \\
2 \%, 2,5 \%, 3 \% \text {. Kontrol positif menggunakan bentan dengan total telur sebanyak } 21 \text { telur } \\
\text { keong mas. Pengamatan dilakukan selama } 14 \text { hari. Hasil penelitian yaitu telur yang tidak } \\
\text { menetas diuji dengan menggunakan One Way ANOVA dan dilanjutkan dengan uji lanjutan } \\
\text { yaitu uji LSD (Least Significant Difference). Hasil penelitian ini menunjukkan bahwa ekstrak } \\
\text { daun jambu biji (Psidium guajava L.) dapat digunakan sebagai ovisida keong mas (Pomacea } \\
\text { canaliculata L.). Konsentrasi ekstrak daun jambu biji } 1 \% \text { ternyata sudah dapat mematikan } \\
\text { keong mas. }\end{array}$ \\
\hline $\begin{array}{l}\text { Keywords: } \\
\text { Guava leaves } \\
\text { (Psidium guajava } \\
\text { L.), golden snail } \\
\text { (Pomacea } \\
\text { canaliculata L.), } \\
\text { Pesticide, Ovicide, } \\
\text { guava leaf extract. }\end{array}$ & $\begin{array}{l}\text { Golden snail is a pest for rice plantation. This pest will eat rice steam in short time. It caused } \\
\text { failed in rice harvesting. The utilization of synthetic pesticide to kill whether snail egg or } \\
\text { mature snail, could endanger surroundings and caused a vector resintance. On the other } \\
\text { hand, natural pesticide only killed mature snail. Therefore, it is need to develop natural } \\
\text { pesticide which could kill snaill eggs. Guava leaves (Psidium guajava L.) extract contained } \\
\text { saponin, flavonoid, tanin, terpenoid, and alkaloid which is predict to have an ability as } \\
\text { ovicide. This research was an experimental research. Design of this research was Complete } \\
\text { Randomized Design (CRD). The concentration of leaf extract was } 1 \%, 1,5 \%, 2 \%, 2,5 \%, 3 \% \text {, } \\
\text { We used bentan as a positive control and total number of snail eggs was } 21 \text {. The observation } \\
\text { was done for } 14 \text { days. All of unhatched eggs had been tested using One Way ANOVA, and } \\
\text { continued to LSD test. This reasearch showed that guava leaf extract has an ability as ovicide } \\
\text { for golden snail eggs. It was showed from } 1 \% \text { extract concentration had killed the eggs. }\end{array}$ \\
\hline
\end{tabular}

\section{PENDAHULUAN}

Indonesia merupakan negara kepulauan yang memiliki beraneka ragam sumber daya alam. Oleh karena itu, negara Indonesia dikenal juga dengan sebutan negara agraris. Pemanfaatan sumberdaya alam di Indonesia sebagian besar digunakan pada bidang pertanian dan perkebunan. Padi (Oryza sativa) adalah tanaman pertanian yang paling banyak ditanam di Indonesia, karena mayoritas penduduk di Indonesia mengkonsumsi nasi sebagai makanan pokok. Tanaman padi termasuk pada tanaman yang rentan serangan hama. Beberapa wilayah di Indonesia rentan akan serangan hama pada pati, tercatat provinsi
Lampung, Jawa Tengah dan Jawa Barat merupakan tiga provinsi teratas yang mngeluhkan serangan hama pada tanaman padi [1].

Hama adalah hewan yang menyebabkan kerusakan pada lahan pertanian sehingga menyebabkan kerugian dalam pertanian. Di Indonesia, ditemukan hama keong mas (Pomacea canaliculata L.) merusak tanaman padi di lima wilayah, yaitu Jawa, Sumatera, Kalimantan, NTB, dan Bali. Keong mas merusak 10-40\% lahan pertanian di lima wilayah tersebut [2]. Keong mas termasuk ke dalam jenis hewan herbivora dan hidup di daerah lembab atau lahan yang memiliki air seperti sawah [3]. 
Keong mas (Pomacea canaliculata L.) merusak tanaman padi dengan cara memakan seluruh batang tanaman padi dalam waktu yang relatif cepat (satu malam). Dampaknya adalah rumpun tanaman padi hilang dan dapat mengakibatkan gagal panen. Oleh karena itu, dibutuhkan cara untuk menanggulangi hama keong mas. Petani pada umumnya menggunakan pestisida sintetik, namun penggunaan pestisida sintetik telah diketahui akan menyebabkan pencemaran lingkungan. Salah satu solusi sebagai pengganti pestisida sintetik adalah penggunaan pestisida nabati. Beberapa penelitian telah menggunakan ekstrak dari tanaman yang memiliki senyawa yang mampu membunuh keong mas. Ekstrak biji pinang, ekstrak serai, dan ekstrak bawang putih telah diketahui dapat membunuh keong mas dewasa. Namun, ketiga ekstrak tersebut belum dapat mematikan telur keong mas. Keong mas selama hidupnya akan menghasilkan telur kurang lebih sebanyak 500 butir, dengan presentase penetasan lebih dari 85\% [4]. Ekstrak daun jambu biji adalah salah satu kandidat pestisida nabati yang dapat membunuh telur keong mas. Ekstrak daun jambu biji (Psidium guajava L.) diketahui memiliki kandungan saponin, flavonoid, tanin, terpenoid,alkaloid, dan steroid [5]. Hingga kini belum dikembangkan penggunaan ekstrak daun jambu biji sebagai ovisida telur keong mas. Oleh karena itu, penelitian ini bertujuan untuk mengetahui kemampuan ekstrak daun jambu biji sebagai ovisida.

\section{EKSPERIMEN}

\section{Material}

Bahan yang digunakan pada penelitian ini adalah daun jambu biji, simplisia, akuades, $\mathrm{H}_{2} \mathrm{SO}_{4}$, etanol $96 \%, \mathrm{FeCl}_{3}$, klorofom, $\mathrm{HgCl}_{2}$, KI, serbuk $\mathrm{Mg}, \mathrm{HCl}$.

\section{Prosedur}

\section{Pembuatan Simplisia}

Daun jambu biji sehat dan segar diperoleh dari Panaragan kabupaten Tulang Bawang Barat. Bagian daun yang digunakan adalah daun yang berada di bagian ke 2 dari pucuk paling dekat dengan sinar matahari. Daun dicuci dan dikeringkan di bawah sinar matahari hingga kering dan dapat dihaluskan hingga mejadi simplisia.

\section{Pembuatan Ekstrak Daun Jambu Biji}

Sebanyak $500 \mathrm{~g}$ simplisia dimasukkan ke dalam labu maserasi dan direndam dengan etanol 96\% sebanyak 2 L selama 48 jam. Selanjutnya, larutan disaring. Supernatan lalu diuapkan dalam rotary evaporator selama \pm 1 jam. Ekstrak pekat yang didapatkan sebanyak $50 \mathrm{~g}$.

\section{Analisis Kualitatif Skrining Fitokimia Daun Jambu biji}

\section{Saponin}

Sebanyak 0,5 mL sampel dilarutkan pada 5 $\mathrm{mL}$ akuades, kemudian dihomogenkan selama 30 detik, jika terdapat buih atau busa menunjukkan positif mengandung saponin.

\section{Steroid}

Steroid dapat diketahui dengan membuat campuran yang terdiri dari $0,5 \mathrm{~mL}$ sampel, $0,5 \mathrm{~mL}$ asam asetat glasial dan $0,5 \mathrm{~mL} \mathrm{H}_{2} \mathrm{SO}_{4}$. Perubahan warna pada sampel yang berubah menjadi biru atau ungu menandakan positif mengandung steroid.

\section{Terpenoid}

Terpenoid dapat diuji dengan cara mencampurkan sampel, asam asetat glasial dan $\mathrm{H}_{2} \mathrm{SO}_{4}$ masing-masing sebanyak $0,5 \mathrm{ml}$. Perubahan warna pada sampel yang berubah menjadi merah atau kuning menandakan positif mengandung terpenoid.

\section{Tanin}

Uji tanin diperoleh dari mencampurkan 1 ml sampel dan 3 tetes larutan $\mathrm{FeCl}_{3}$ 10\%. Warna yang berubah pada larutan menjadi hitam kebiruan menandakan positif mengandung tanin.

\section{Alkaloid}

Sebanyak 0,5 $\mathrm{ml}$ sampel dan 5 tetes kloroform ditambahkan pereaksi mayer, yaitu $1 \mathrm{~g}$ $\mathrm{Kl}$ dilarutkan dalam $20 \mathrm{ml}$ akuades, kemudian ditambahkan lagi dengan $0,271 \mathrm{~g} \mathrm{HgCl}_{2}$ hingga larut, jika menunjukkan perubahan warna pada larutan, menjadi putih kecoklatan menandakan positif mengandung alkaloid. 


\section{Flavonoid}

Sampel sebanyak $0,5 \mathrm{ml}$ ditambahkan $0,5 \mathrm{~g}$ serbuk $\mathrm{Mg}$ dan $5 \mathrm{ml} \mathrm{HCl}$ pekat yaitu tetes demi setetes, adanya perubahan pada larutan menjadi merah atau kuning dan ada busa menandakan positif mengandung flavonoid [6].

\section{Ovisida}

Konsentrasi (b/v) ekstrak daun jambu biji yang digunakan adalah $0 \% ; 1 \% ; 1,5 \% ; 2 \% ; 2,5 \%$; $3 \%$. Uji ekstrak daun jambu biji dilakukan dengan cara menimbang berat dan menghitung jumlah telur keong yang diletakkan dalam cawan petri sebanyak 6,6 gram dan luas $50,24 \mathrm{~cm}^{2}$ telur, panjang kelompok telurnya sekitar $1-3 \mathrm{~cm}$, diameter sekitar $2 \mathrm{~cm}$. Melakukan pengamatan dan penyemprotan setelah 24 jam sekali selama 14 hari, telur keong mas yang diamati adalah jumlah telur keong emas yang tidak menetas dianggap mati setelah lebih dari waktu saat pengamatan selama 14 hari. Pengujian dilakukan dengan 7 perlakuan dan 3 kali pengulangan.

\section{HASIL DAN PEMBAHASAN}

\section{Uji Fitokimia}

Hasil uji kualitatif fitokimia ekstrak daun jambu biji memperlihatkan tidak ditemukannya steroid dapat dilihat pada Tabel 1.

Tabel 1. Hasil uji fitokimia

\begin{tabular}{clc}
\hline No. & Jenis Uji & Hasil Uji \\
\hline 1 & Saponin & + \\
2 & Steroid & - \\
3 & Terpenoid & + \\
4 & Tanin & + \\
5 & Alkaloid & + \\
6 & Flavonoid & + \\
\hline
\end{tabular}

\section{Ovisida Telur Keong Mas}

Uji ekstrak daun jambu biji sebagai ovisida keong mas telah dilaksanakan penelitiannya selama 14 hari. Uji ekstrak daun jambu biji sebagai ovisida keong mas menunjukkan bahwa semakin tinggi konsentrasi yang digunakan maka yang terjadi pada daya hambat penetasan telur keong mas juga semakin tinggi. Rata-rata jumlah penurunan telur keong mas yang tidak menetas menjadi keong mas selama 14 hari digambarkan secara umum dalam bentuk Gambar 1.

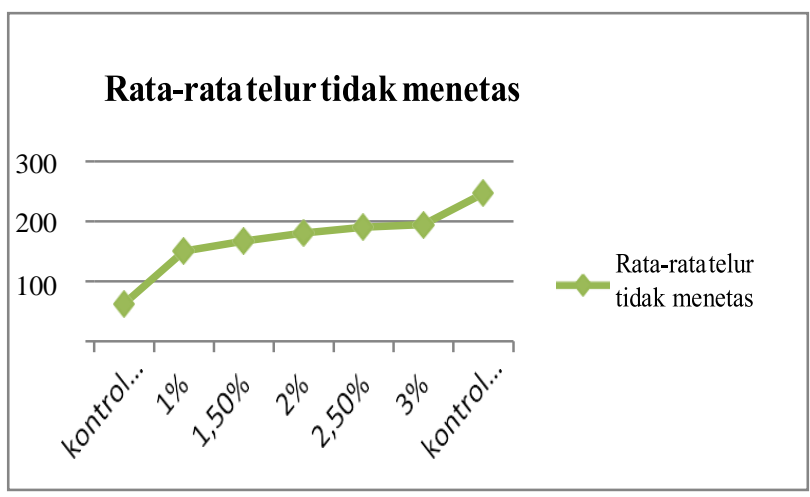

Gambar 1. Rerata Jumlah Telur Tidak Menetas Selama 14 Hari.

Metabolit sekunder yang menghambat perkembangan telur keong mas adalah flavonoid, karena flavonoid dapat bertindak sebagai hormon juvenile yang membuat telur tidak dapat menetas menjadi menjadi keong mas [7].

Senyawa yang berfungsi seperti hormone juvenil selain dari flavonoid adalah terpenoid. Terpenoid juga akan menghambat perkembangan telur keong mas [8]. Alkaloid juga memiliki fungsi sebagai juvenil hormon, aktivitas tersebut dapat mengganggu sistem kerja saraf pusat dan merusak membran sel telur keong mas sehingga gagal untuk menetas [9].

Indeks keberhasilan didapatkan dari kemampuan untuk membuka cangkang selama 14 hari.

\section{Uji Statistik}

Uji One Way ANOVA digunakan untuk mengetahui apakah ada pengaruh yang dihasilkan oleh ekstrak daun jambu biji sebagai ovisida keong mas. Tabel 2 adalah hasil perhitungan uji One Way ANOVA.

Tabel 2. Hasil perhitungan One Way ANOVA

\begin{tabular}{llllll}
\hline Sumber & Derajat & Jumlah & Kuadrat & F & F \\
Kegunaan & Bebas & Kuadrat & Tengah & Hitung & Tabel \\
\hline Ovisida & 6 & 57351,143 & 9558,524 & 11,012 & 2,850 \\
Galat & 14 & 12152,667 & 868,048 & & \\
Total & 20 & 69503,810 & 10426,572 & & \\
\hline
\end{tabular}

Jika Fhitung $>$ Ftabel maka dinyatakan $\mathrm{H}_{0}$ ditolak dan $\mathrm{H}_{1}$ diterima.dengan kata lain bahwa ada pengaruh ekstrak daun jambu biji (Psidium guajava L.) dengan variasi konsentrasi $0 \%, 1 \%$, 
$1,5 \%, 2 \%, 2,5 \%, 3 \%$ sebagai ovisida keong mas (Pomacea canaliculata L.), dan yang memberikan pengaruh paling tinggi sesuai dengan kriteria yang terdapat pada $\mathrm{H}_{1}$ adalah konsentrasi $3 \%$ sebanyak $16,33 \% . \mathrm{H}_{1}$ diterima yang artinya memiliki pengaruh. Untuk mengetahui perbedaan pengaruh antar konsentrasi perlakuan, dilakukan pengujian lanjutan dengan uji Least Significance Different (LSD) yang dapat dilihat pada Tabel 3 di bawah ini.

Tabel 3. Hasil Uji LSD

\begin{tabular}{cc}
\hline Konsentrasi & $\begin{array}{c}\text { Rata-rata jumlah telur keong } \\
\text { mas yang tidak menetas }\end{array}$ \\
\hline $0 \%$ (aquad) & $61,67^{\mathrm{a}} \pm 10,41$ \\
$1 \%$ & $150,00^{\mathrm{b}} \pm 22,91$ \\
$1,5 \%$ & $166,67^{\mathrm{b}} \pm 25,66$ \\
$2 \%$ & $180,00^{\mathrm{b}} \pm 18,03$ \\
$2,5 \%$ & $190,00^{\mathrm{b}} \pm 57,67$ \\
$3 \%$ & $194,33^{\mathrm{b}} \pm 22,94$ \\
+ (bentan) & $246,7^{\mathrm{c}} \pm 24,66$ \\
\hline
\end{tabular}

Uji LSD menjelaskan pada kontrol negativ berbeda signifikan dengan konsentrasi lainnya. Konsentrasi $1 \%$ tidak berbeda signifikan dengan konsentrasi $1,5 \%, 2 \%, 2,5 \%$ dan $3 \%$ tetapi berbeda signifikan dengan kontrol positif dan negatif. Kontrol positif berbeda signifikan dengan konsentrasi lainnya. Dari tabel juga terlihat bahwa rata-rata pada telur yang tidak menetas menjadi keong mas pada control negative adalah 61,67; pada konsentrasi $1 \%$, $1,5 \%, 2 \%, 2,5 \%$, dan $3 \%$ berturut-turut adalah $150 ; 166,67 ; 180 ; 190 ; 194,33$ dan pada control positif yaitu 246,7.

Rerata telur yang tidak menetas menjadi keong mas terlihat dari konsentrasi tinggi ke konsentrasi terendah, yaitu 3\%, 2,5\%, 2\%, 1,5\%, dan $1 \%$. Hal ini terjadi dikarenakan kandungan senyawa metabolit pada ekstrak dari daun jambu biji bekerja engan baik, yaitu semakin tinggi konsentrasi yang digunakan pada penelitian, maka rata-rata telur yang tidak menetas menjadi keong mas semakin tinggi pula.

\section{SIMPULAN}

Ekstrak daun jambu biji mampu dimanfaatkan sebagai ovisida pada keong mas. Perbadaan konsentrasi ekstrak daun jambu biji pada $1 \%, 1,5 \%, 2 \%, 2,5 \%$, dan $3 \%$ menunjukkan hasil yang tidak berbeda signifikan pada konsentrasi yang artinya dari konsentrasi $1 \%$ sudah dapat mematikan keong mas, tetapi dari hasil uji LSD rata-rata jumlah telur yang tidak menetas tertinggi adalah $3 \%$.

\section{REFERENSI}

[1] N. R. Isnaningsih dan M. R. Marwoto, "keong hama pomacea di indonesia: karakter morfologi dan sebarannya (mollusca, gastropoda: ampullaridae)," Jurnal Ilmu-Ilmu Hayati, vol. 10, no. 4, 2011.

[2] Budiyono dan Suharto, "Teknik mengendalikan keong mas pada tanaman padi (the technical controling of golden snail on pant rice)," Jurnal Ilmu-ilmu Pertanian, vol. 2, no. 2, pp. 128-132, 2006.

[3] L. Jum'ati, "Pengaruh sari eceng gondok (Eichornia crassipes Solms.) terhadap keong mas (Pomaceae canaliculata Lamarck)," Prog Studi Pedidikan Biologi Sekolah Tinggi Keguruan dan Ilmu Pendidika (STKIP) PGRI Sumatera Barat, Padang, Artikel 2016.

[4] S. Putra dan S. Zein, "Pengaruh variasi konsentrasi ekstrak serai (Andropogon nardus) terhadap mortalitas hama keong mas (Pomaceae caniculata L.)," Jurnal Pendidikan Biologi, vol. 7, no. 1, 2016.

[5] Dwitiyanti, "Daun jambu biji (Psidium guajava L.) sebagai anti kanker payudara," Jurnal fakultas Farmasi dan Sains Universitas Muhammadiya Prof. Dr. Hamka, vol. 2, no. 2, Agustus 2015.

[6] Tasmin , N. Erwin, Kusumma, dan Irawan W, "Identifikasi dan uji toksisitas senyawa flavonoid fraksi kloroform dari daun terap ( $A$. odoratissimus Blanco.)," Jurnal Isolasi, Universitas Mulawarman, 2014.

[7] S. Diah A., E. Setyaningrum, A. Wahyuni, and B. Kurniawan, "Efektivitas ekstrak buah mahkota dewa merah (Phaleria macrocarpa Boerl.) sebagai Ovisida Aedes aegypti", Medical Journal of Lampung University, vol. 3, no. 2, 2014.

[8] R. Raveen, F. Ahmed, M.Pandeeswari, D.Reegan, S.Tennyson, S.Arivoli, dan M.Jayakumar, "Laboratory evaluation of few plants extract for their ovicidal, larvacidal, and pupicidal activity againt medically important human dengue, chikungunya and zika virus vector, aedes aegypti linnieus", International Journal of Mosquito Research, vol. 4, no. 4, 2017.

[9] I. S. Rohaya, E. Aryanti, dan Suripto, "Kandungan fitokimia beberapa jenis tumbuhan lokal yang sering dimanfaatkan sebagai bahan baku obat di pulau lombok," Prosiding Sem Nas Masy Bi Odiv Indonesia, vol. 1, no. 2, pp. 388-391, 2015. 